\section{Do You Remember that Moment You, You Know, Became a Reader?}

As editor of this column, I enjoy the rich experiences, anecdotes, and research that professionals share within these columns. They provide a source of affirmation, statistical evidence, data and "feel good" stories that add value to our knowledge about readers' services. For many of us, it's refreshing to read thoughts from like-minded professionals, as we find ourselves nodding in agreement or opposition against what other professionals are sharing with us. What we don't always write about are the moments we share with colleagues over a cup of coffee or tea. Those stolen moments when you just want to share a heart-warming conversation you had with a reader, or the small moments littered throughout a day, week, month, or year that make you fall in love with reading all over again. In particular, those moments readers tell you when they became readers and how powerful those stories are when told._Editor

Did you know I didn't go to school or begin to read as other children do? I was sick as a child and wasn't able to go to school, but spent my childhood in bed at a hospital. I didn't know how to read and was years behind. But, when I finally went to school around age 7, a teacher changed my life. Most children thought she was strict and mean, but she opened up a world for me- the world of books and reading. She had an old tobacco tin and would pull out letters that I'd sort and identify. Those letters soon became words. From those words, I began to read sentences. Sentences developed into stories and at that moment, I was lost to a world of books that changed my life. That teacher made me a reader and I will never forget her.

t's so easy to forget why or when we fell in love with reading. It's so easy to forget how comforting our relationship with books, characters, and the written word is in our daily lives, because it is so familiar. We take it for granted. We expect others share that unspoken "it" and that others just get it when we pause and reflect on when we became a reader. But, in the past week or month, how often have you found yourself pausing and re-experiencing that moment you fell in love with reading? That moment, book, person, or character that altered how you thought about reading forever? Until recently, I must admit it had been years. Sadly, like many of us, it's not as if I haven't been an avid reader or active professional. Rather, I was bogged down in theory, professional obligations, statistics and just a sense of purpose for "getting the job done."

For half a decade I have been teaching graduate studies at a local university in a school of information management. I've been supporting new professionals find their path to 
becoming professional librarians, and passing along anecdotes and any knowledge I can share to prepare those students for practicing in the profession. One of those courses is Reading and Reading Practices. This is a course focussed on asking questions such as: "what is reading?" "what makes a reader, and how do we define a reader?" "why and what do we choose to read?" and "how do we support and encourage reading"? These questions start a dialogue that lasts the entire semester. Prior to that, I was a librarian at a public library and an active member of the readers' advisory team. Yet (silence) . . . yet I didn't reflect on those books or pivotal moments that shaped my reading experiences from reading passively, to having my life changed, altered forever, by reading experiences that defined me as a reader. As the title of this article suggests, "you know, that moment you became a reader."

This past September I started a new position as a school librarian. It is the first time in years that the school has had a librarian. Maybe it's the new position, the school environment, or my own love of books, but this past year has been filled with remarkable and emotional stories from faculty and students involving their reading experiences. The story at the beginning of this article is an example of one of these pivotal moments. Interestingly, she hadn't shared this with other members of our faculty, but me, the new librarian. I'd like to think our conversation was the result of two kindred spirits, drawn together because of our love for books. But, I also think it might have been something more. It was at the end of the day, the sun was coming in the windows and we were just chatting. In some ways, the mood was set for a more intimate conversation because the day was over, and we were just two individuals sharing a conversation. We were discussing common interests and the conversation naturally and gradually led to reading, favorite books, and "that moment" we fell in love with reading. This isn't the only story that stands out among the book conversations I've had this year. Just yesterday, speaking with the principal of the elementary school, he brought up the importance of having a librarian. In particular, his belief that a librarian's presence in the school will foster an increasing number of students to experience that pivotal moment that changes their reading experiences. For him, he somewhat sheepishly expressed that his own love of reading didn't start until ninth grade, when he read To Kill a Mockingbird. It was with that book that he experienced the realization that reading was a pleasure and an emotional experience rather than just a means to an end.

For a readers' advisor, these are the type of meaningful conversations we dream of having — conversations where we have time to talk, to relate to our readers, and have special reading experiences shared with us. Out of these conversations, we are privileged to have a glimpse into the moment an individual becomes a reader, and to discover small breadcrumbs we can trace into reading patterns, favorite authors, and appeals. While I can take a step back and reflect on this experience as a readers' advisor, I can also appreciate it as a reader and lover of books. In fact, in some ways, it might have created an even greater appreciation for what readers' advisors-you and I-do, because I was part of the conversation, and not placed in a position where I felt I had to recommend or suggest a book. What a way to rekindle, or perhaps, reawaken, why we do what we do. There's a passion and a story behind every reader. Duncan Smith often talks about this in his writings and presentations. If we pause and take a moment to reflect on our reading choices, each of us can tell a story about our reading journey, preferences and key moments, interests or people who have shaped our relationship with reading. Intellectually, we know this. But it isn't often we experience this frequently, and are able to indulge in the emotional experience of these stories. For me, I am experiencing a profound and exciting rebirth in my belief in readers' advisory and an increased purpose behind why I choose to promote, encourage, and support reading and literacy every single day.

\section{THE PLEASURE OF READING}

Many of you may be familiar with the book The Pleasure of Reading: 43 Writers on the Discovery of Reading and the Books that Inspired Them. Edna O'Brien, a contributor to this collection, talks about the reader's experience with a book; the transformation into a pleasure reader and when that first relationship is experienced. Using her words, O'Brien states "reading, for me, then as now, is not a pleasure, but something far more visceral, a brush with terror. ... Words were talismanic, transfiguring, making everything clearer, and at the same time more complex. Words were the sluice gates to the mind and to the emotions" 1

I have often been told that from birth until around the third grade, a child learns to read and begins an introductory relationship with books. It is after grade 3 that a child begins to read to learn. Is this, in a very simplified and innocent sense, what the average eight- or nine-year-old experiences during that transition from "learning to read," to "reading to learn"? Is this the turning point or foundation that sets that stage for a student who reads to become a reader?

In working at a public library and as a member of the readers' advisory team, there is often a sense that we, as librarians "own" readers' services. Even as a school librarian, I am guilty of thinking at times that I am sole owner of readers' services and that it is my responsibility to create and foster that "aha" moment; that experience when a child, teen, or adult has that visceral, emotional reaction to a book or character that changes their life. In "Fostering Ownership of the Reading Experience," Harms and Lettow explore the idea that lifelong readers develop from an ability to take part in their own reading experience. Indeed, the article views teachers as allies in developing a strong (positive) emotional connection with reading. They write, "If children learn to read by making sense through exploring, experiencing, and discovering (Smith, 1982), they need to be given ownership of this process, too." ${ }^{2}$ Harms and Lettow go on to state, 


\section{READERS' ADVISORY}

The teacher's role in assisting children to own their reading experience is to collaborate with them, as Smith describes it, to create an environment in which (1) meaningful reading experiences with whole unites of language are provided to foster personal/social development and (2) many opportunities are available to use the ideas gained from reading in one's immediate setting. ${ }^{3}$

In our profession, we often work with teachers and schools. We focus on supporting curriculum, on reading programs, and other projects, partnerships, and opportunities that come our way. But when we discuss the reading experience, and focus on readers' services, we don't often include or reflect on the role of the teacher. It isn't that we don't want to include them, or don't realize their value, but as librarians, and specifically public librarians, they aren't in our immediate reach. As a school librarian, it is becoming increasingly obvious that schools should and need to create the building blocks and set the stage for a child to become a life-long reader. If a child's reading experience is not positive or fostered by teachers, it is more than likely that these will be the individuals that librarians find themselves facing as reluctant readers and adult burgeoning readers. Indeed, through all of the conversations I've had with students and faculty these past months, the "moment" when that pivotal reading experience occurs has happened no later than age 15. Fascinating. While this is a small sampling of cases, and some might disagree, the age group where this seems to be happening is something to note. For youth librarians and readers' services for those age groups, many of you might be nodding your head in agreement, having witnessed firsthand young peoples' reading transformations during these years.

As readers' advisors we often are confronted with the child who views reading as work; as a means to an end. As mentioned previously, this was true of our school's elementary principal. He echoes Harms' and Lettow's ideas that a child's school reading experiences heavily impact ideas about reading for pleasure. Children who have enjoyed reading or have the potential to enjoy reading "may find to their disappointment that reading in school means learning the alphabet in isolated letter/sound relationships, drilling on these elements, and swiftly completing worksheets that require underlining and matching.".4
Yet, for many children, the love of stories and language prevails, no matter their experience. Some readers may experience their "moment" later in life, but stories have always held power and fascination. As such, our focus on appeals and the reader as an individual and not a one-size-fits-all model continues to provide opportunities for children and adults of all ages to build relationships with books. While we might not be the one who provides the pivotal moment in a readers' life, we can certainly strive to continue to grow and support the relationship readers have with reading.

As evidenced by the stories shared with me as I sit at my desk or walk through the school halls, the pivotal moments continue to happen. And when we are fortunate enough, these stories of "the moment" are shared with us. Isn't that why we continue to do what we do? While reading The Pleasure of Reading, there was a quote that I found intriguing and compelling in its honesty. Ronald Harwood, in speaking of his excitement and childhood wonder over his favorite books and characters states: "I have not, except for Treasure Island, reread them since childhood or adolescence and I've made it a condition not to reread them now in case I am embarrassed by memory. I want to prevent the pompous adult, sensitive to what others may think, from inhibiting the impressionable child." ${ }^{5}$

Those reading experiences, so pivotal and, as O'Brien expresses, sometimes visceral, are to be cherished. We don't want them over-shadowed, spoiled, or taken away. We want to share them, in all of their wonder and innocence. Isn't that what we ultimately hope to achieve as readers' advisors? While we are all guilty of slogging away and sometimes thinking "it's the best I can suggest," don't we all want to make that difference to a reader? To find the book that speaks to them, so that they remember and cherish that experience?

Do you remember that moment you, you know, became a reader?

\section{References}

1. Antonia Fraser, The Pleasure of Reading: 43 Writers on the Discovery of Reading and the Books that Inspired Them (London: Bloomsbury, 2015).

2. J. M. Harms and L. J. Lettow. "Fostering Ownership of the Reading Experience," The Reading Teacher 40, no. 3 (December 1986): 324

3. Ibid., 324-25.

4. Ibid., 325.

5. Fraser. 128. 